\title{
ISOLATION OF SURFACTANTS SYNTHESIZED BY THE PSEUDOMONAS BACTERIA AND STUDY OF THEIR PROPERTIES
}

\author{
T.Ya. Pokynbroda ${ }^{1 *}$, I.V. Karpenko ${ }^{1}$, H.H. Midyana ${ }^{1}$, O.Ya. Karpenko ${ }^{2}$ \\ ${ }^{1}$ Department of Physical Chemistry of Fossil Fuels InPOCC, NAS of Ukraine, Lviv, Ukraine \\ ${ }^{2}$ Lviv Polytechnic National University, Lviv, Ukraine \\ *Corresponding author: pokynbroda@ukr.net \\ Received 28 February 2019; Accepted 19 April 2019
}

\begin{abstract}
Background. The important problem of biosurfactants production is biosynthesis optimization. But lack of effective isolation methods elaboration with simultaneous new costeffective products is the greatest weaknesses of existing technologies.

Objective. The aim of the study is rational technology elaboration for isolation of biosurfactants obtained from strains Pseudomonas sp. PS-17 and P. fluorescens 8573. Investigation of the influence of different acids and temperatures on the efficiency of isolation of the surfactant products, study the properties of the obtained products. Determination of the possible directions of the use of supernatant obtained after precipitation of the biocomplexes (SPL) as a new inexpensive product.

Methods. Rhamnolipid surfactant concentrate was precipitated from culture liquid supernatant (CLS) by acidification to $\mathrm{pH}$ 3-4 with acid solutions $\left(\mathrm{HCl}, \mathrm{H}_{2} \mathrm{SO}_{4}, \mathrm{H}_{3} \mathrm{PO}_{4}, \mathrm{HNO}_{3}, \mathrm{CH}_{3} \mathrm{COOH}\right)$, kept at $100{ }^{\circ} \mathrm{C}$ for $25 \mathrm{~min}$, cooled to room temperature, centrifuged before the phase separation, the supernatant was decanted. The surface tension of the SPL was determined by du Noüy method (with a platinum ring). The emulsification index of biosurfactants was determined regarding mineral oil and sunflower oil. The RLs were isolated from the SPL by extraction with a mixture of ethyl acetate and isopropanol, their composition was determined by thin layer chromatography. Influence on plants was assessed by their morphometric parameters after presowing seed treatment.

Results. The rational technology for surfactants isolation from strains Pseudomonas sp. PS-17 and P. fluorescens 8573 was developed It was shown that the suitable method of the isolation of the biosurfactants of Pseudomonas sp. PS-17 and P. fluorescens 8573 is acidic precipitation from CLS with heating. As a result, the product yield was increased by $20 \%$, and the duration of the process was reduced. The physico-chemical properties of the SPLs after the isolation of biosurfactants from the CLS were studied. SPLs have been shown to be effective oil emulsifiers, foaming and wetting agents for various surfaces. It was shown that SPLs (at dilutions 1:10) do not exhibit phytotoxic effects and stimulate the growth of watercress.

Conclusions. The new wasteless technology for Pseudomonas strains biosurfactants isolation has been proposed, which provides for the elimination of the extraction stage with solvents, as a result, the yield of the target products has been increased. Thus, the technology has economic and environmental advantages. It was shown that SPLs, being inexpensive and effective products, can be used in environmentally friendly technologies: in agriculture (for stimulation of plant growth), for remediation of contaminated soils, production of detergent compositions.
\end{abstract}

Keywords: rhamnolipid surfactants; physicochemical properties; acid precipitation; plant growth stimulators.

\section{Introduction}

Nowadays environmental technologies have become a priority, so biogenic surfactants are considered as an alternative to synthetic [1]. Among the promising producers, the bacteria of the genus Pseudomonas deserve the attention, since they synthesize the rhamnolipids (RLs) with high surface activity. According to their chemical structure, RLs are the ethers of rhamnose and fatty acids. Due to their diphylic structure, the biosurfactants are characterized by the same properties as synthetic ones: surface and interfacial tension, critical mi- celle concentration, hydrophilic-lipophilic balance, stabilization of hydrocarbon emulsions, foaming ability, etc. Rhamnolipids are able to reduce the surface tension of solutions up to $29 \mathrm{mN} / \mathrm{m}$, emulsify a number of hydrocarbons, vegetable oils, mineral oils, petroleum, etc. In aqueous solutions, biosurfactants are adsorbed on solid surfaces, changing their adhesion and wetting. RLs specifically influence the microorganisms and viruses: they provide antimicrobial effects in higher concentrations while increasing the permeability of cell membranes in lower concentrations. These properties of biosurfactants determine their ability to enhance the ac-

(c) The Author(s) 2019. Published by Igor Sikorsky Kyiv Polytechnic Institute. This is an Open Access article distributed under the terms of the license CC BY 4.0 (https://creativecommons.org/licenses/by/4.0/), which permits re-use, distribution, and reproduction in any medium, provided the original work is properly cited. 
tion of other substances while using them. They can be used in agriculture (complex plant protection and nutrition), in the food, pharmaceutical and cosmetic industries. Thus, due to physicochemical properties combined with the biocompatibility the rhamnolipid surfactants can replace synthetic products in environmentally priority technologies.

Nowadays the economic accessibility of biosurfactants is limited by the cost of their synthesis, and even more by the costs of isolation and purification of the products. In addition, the knowledge of physico-chemical and biological properties of biosurfactants, which are necessary for assessing their practical potential, is not always complete [2]. The most problematic stage in the production of RLs is their isolation from the culture liquid. Even with optimized biosynthesis, the production efficiency depends heavily on rational methods of isolation of the target products. In this connection, there is a growing need for the optimization of the processes of isolation of biosurfactants. For instance, the cost of raw materials is up to $20-40 \%$ of the total cost of production [3]. To replace traditional substrates (sugar, alcohol) it is proposed to use economically viable carbon sources (industrial wastes, renewable substrates, etc.) $[4,5]$. Previously, soybean, sunflower oils, technical glycerol a by-product of biodiesel production were used for the rhamnolipid biosynthesis [6-8], the mathematical methods were applied for the synthesis optimization [9-11]. However, it is known, that the processes of biosurfactants allocation are up to $50-80 \%$ of the total cost of their production [2]. Currently, solvents are often used for extraction of pure biosurfactants, but they do not fully extract products, and also are toxic [12]. The economic availability of rhamnolipids technology can be increased via obtaining their complexes: culture liquid supernatant (CLS), rhamnolipid biocomplex, etc. The maximum use of components of the post-fermentative culture liquid is also a rational way to the production efficiency.

The aim of the present study is the rational technology elaboration for isolation of biosurfactants obtained from strains Pseudomonas sp. PS-17 and P. fluorescens 8573 . The tasks of the study: to investigate the influence of different acids and temperature conditions on the efficiency of isolation of the surfactant products of Pseudomonas strains and to study the properties of the obtained products. To determine the possible directions of the use of supernatant obtained after precipitation of the biosurfactants as a new inexpensive product.

\section{Materials and methods}

The following strains were used for the study: Pseudomonas sp. PS-17 and P. fluorescens $8573-$ producents of extracellular biosurfactants from the collection Department of Physico-Chemistry of Fossil Fuels of L.N. Litvinenko InPOCC, NAS of Ukraine. Cultivation was carried out on a rotary shaker, $220 \mathrm{rpm}$, (WL-2000, JV Electronic, Poland), $30^{\circ} \mathrm{C}, 5$ days [6]. Rhamnolipid biocomplex was precipitated from CLS [13] by acidification to pH 3-4 with acid solutions $\left(\mathrm{HCl}, \mathrm{H}_{2} \mathrm{SO}_{4}, \mathrm{H}_{3} \mathrm{PO}_{4}\right.$, $\mathrm{HNO}_{3}, \mathrm{CH}_{3} \mathrm{COOH}$ ), kept at $100{ }^{\circ} \mathrm{C} 25 \mathrm{~min}$, cooled to room temperature, centrifuged $(8000 \mathrm{rpm}$, $20 \mathrm{~min}$ ) before the phase separation, the supernatant obtained after precipitation of the biosurfactants (SPL 1) was decanted. For comparison, biosurfactant was isolated from the acidified CLS upon cooling $\left(4^{\circ} \mathrm{C}\right)-\mathrm{SPL} 2$. The surface tension of the SPL was determined by du Noüy ring method with a platinum ring on the Tensiometer KRbSS K6 ("KRÜSS" Gmbh, Germany) [14], the relative concentration of biosurfactants was determined by the critical micellar dilution (CMD) [15]. The emulsification index of SPL $\left(E_{24}\right)$ was determined with respect to vaseline oil and sunflower oil. The RLs were isolated from the SPL by extraction with a mixture of ethyl acetate isopropanol 2:1, their composition was determined by thin layer chromatography (Merck Silica gel 60, Germany), chloroform-methanol-water 65:2:4, visualization - by 5\% phosphomolybdic acid [16]. Presowing treatment of watercress seeds was carried out by soaking in SPL, sprouting, germination was determined according to State Standard of Ukraine DSTU 4138-2002 [17]. The contact angles of wetting of the SPL were determined on the cathetometer KM-8, foaming formation - according to State Standard of Ukraine DSTU 3789-98 [18]. The experiments were repeated three times. The results were statistically processed using Microsoft Excel software by the method of average error.

\section{Results}

The new technology for surfactants isolation of the strains Pseudomonas sp. PS-17 and P. fluorescens 8573 was developed.

The CLS was acidified (to a $\mathrm{pH}$ of 2.5-4.0), then heated (Method 1) or cooled (Method 2), centrifuged to obtain SPL 1 and SPL 2 and a concentrate of rhamnolipid surfactant (Table 1). 
It was shown that when the acidified CLS of both strains was heated, the yield of the rhamnolipid surfactant concentrate increased by $7-28 \%$, depending on the acid nature. The maximum yield was $6.6 \mathrm{~g} / \mathrm{L}$ for Pseudomonas sp. PS-17 (with $\mathrm{HCl}$ ), for $P$. fluorescens $8573-6.2 \mathrm{~g} / \mathrm{L}$ (with $\mathrm{H}_{2} \mathrm{SO}_{4}$ ). The properties of the obtained SPL were studied to assess their practical potential. It was fined that $3-5 \mathrm{~g} / \mathrm{L}$ of the lipids have remained in the SPL (depending on the method used) (Tables 1, 2). SPLs, obtained by acidification and followed CLS cooling (method 2), are capable of emulsifying hydrophobic substances $\left(\mathrm{E}_{24}-45-\right.$ $59 \%$ - for sunflower oil, 40-50\% - for vaseline oil), so they can be used as emulsifying agents of various oils, fats, hydrocarbons, etc.

SPLs promotes the wetting of surfaces (Table 2). The contact angle of wetting the geranium leaves by solutions of SPLs, obtained by the method 1 was $75^{\circ}$, and by the method $2-15-30^{\circ}$ (for water $\left.110^{\circ}\right)$. A similar effect was obtained for a hydrophobic surface of polytetrafluorethene (PTF). Thus, SPLs can be used in the composition of agricultural agents and other means for wetting enhancement.

For practical application of SPLs of Pseudomonas sp. PS-17 strain, their phytotoxicity was assessed with the test plant - Lepidium sativum (Table 3).

SPLs (1:10) do not exhibit phytotoxic effect; they even stimulate the growth of Lepidium sativum: its morphometric indices were increased. The length of the shoots was on $5-18 \%$ higher than control (4 days), the length of the roots - on 6-17\%, similar effects were observed after 9 days and 16 days. Therefore, SPL is a low-toxic product.

Table 1: Effect of various acids and temperatures on the yield of Pseudomonas biosurfactants

\begin{tabular}{|c|c|c|c|c|c|c|c|c|}
\hline \multirow[b]{3}{*}{ Acid } & \multicolumn{4}{|c|}{ Pseudomonas sp. PS-17 } & \multicolumn{4}{|c|}{ P. fluorescens 8573} \\
\hline & \multicolumn{2}{|c|}{$4^{\circ} \mathrm{C}, 24 \mathrm{~h}$} & \multicolumn{2}{|c|}{$100^{\circ} \mathrm{C}, 25 \mathrm{~min}$} & \multicolumn{2}{|c|}{$4^{\circ} \mathrm{C}, 24 \mathrm{~h}$} & \multicolumn{2}{|c|}{$100^{\circ} \mathrm{C}, 25 \mathrm{~min}$} \\
\hline & $\begin{array}{c}\text { Rhamnolipid } \\
\text { concentrate, } \\
\mathrm{g} / \mathrm{L}\end{array}$ & $\begin{array}{c}\mathrm{RL} \text { in SPL, } \\
\mathrm{g} / \mathrm{L}\end{array}$ & $\begin{array}{c}\text { Rhamnolipid } \\
\text { concentrate, } \\
\text { g/L }\end{array}$ & $\underset{\mathrm{g} / \mathrm{L}}{\mathrm{RL} \text { in } \mathrm{SPL},}$ & $\begin{array}{l}\text { Rhamnolipid } \\
\text { concentrate, } \\
\text { g/L } \\
\end{array}$ & $\underset{\mathrm{g} / \mathrm{L}}{\mathrm{RL} \text { in SPL, }}$ & \begin{tabular}{|c|}
$\begin{array}{c}\text { Rhamnolipid } \\
\text { concentrate, } \\
\mathrm{g} / \mathrm{L}\end{array}$ \\
\end{tabular} & $\begin{array}{c}\mathrm{RL} \text { in } \mathrm{SPL}, \\
\mathrm{g} / \mathrm{L}\end{array}$ \\
\hline $\begin{array}{l}\mathrm{CH}_{3-} \\
\mathrm{COOH}\end{array}$ & -016 & 3.9 & +012 & 3. & 0.12 & 0.3 & \pm 0.13 & .3 \\
\hline $\mathrm{H}_{3} \mathrm{PO}_{4}$ & $5.39 \pm 0.12$ & $4.6 \pm 0.3$ & $6.20 \pm 0.13$ & $3.9 \pm 0.3$ & $5.68 \pm 0.15$ & $4.8 \pm 0.2$ & $5.79 \pm 0.21$ & $3.7 \pm 0.2$ \\
\hline $\mathrm{HCl}$ & $5.44 \pm 0.15$ & $4.6 \pm 0.4$ & $6.59 \pm 0.15$ & $3.3 \pm 0.3$ & $5.21 \pm 0.16$ & $4.4 \pm 0.2$ & $6.13 \pm 0.26$ & $3.5 \pm 0.3$ \\
\hline $\mathrm{H}_{2} \mathrm{SO}_{4}$ & $5.41 \pm 0.21$ & $4.5 \pm 0.5$ & $5.86 \pm 0.15$ & $3.7 \pm 0.3$ & $5.17 \pm 0.13$ & $4.2 \pm 0.3$ & $6.20 \pm 0.19$ & $3.6 \pm 0.3$ \\
\hline $\mathrm{HNO}_{3}$ & $5.32 \pm 0.31$ & $4.8 \pm 0.5$ & $6.39 \pm 0.18$ & $3.1 \pm 0.2$ & $5.54 \pm 0.14$ & $4.6 \pm 0.2$ & $5.63 \pm 0.18$ & $3.9 \pm 0.2$ \\
\hline
\end{tabular}

Table 2: Physico-chemical properties of the SPLs of Pseudomonas sp. PS-17 strain obtained by various methods (pH 7)

\begin{tabular}{|c|c|c|c|c|c|c|c|}
\hline \multirow{2}{*}{ Product } & \multirow{2}{*}{$\begin{array}{c}\text { Acid for } \\
\text { precipitation }\end{array}$} & \multirow{2}{*}{$\begin{array}{c}\text { Foam } \\
\text { stability, \% }\end{array}$} & \multicolumn{2}{|c|}{$\mathrm{E}_{24}, \%$} & \multicolumn{2}{|c|}{$\begin{array}{c}\text { Contact angles } \\
\theta, \text { deg. }\end{array}$} & \multirow{2}{*}{$\begin{array}{c}\text { Surfactant } \\
\text { content, } \\
\text { g/L }\end{array}$} \\
\hline & & & $\begin{array}{c}\text { Sunflower } \\
\text { oil }\end{array}$ & $\begin{array}{l}\text { Vaseline } \\
\text { oil }\end{array}$ & PTF & $\begin{array}{l}\text { Leave of } \\
\text { geranium }\end{array}$ & \\
\hline \multirow{2}{*}{ SPL 1} & $\mathrm{HCl}$ & $50.3 \pm 0.7$ & $20.5 \pm 0.5$ & $1.5 \pm 0.5$ & $40.3 \pm 0.7$ & $75.3 \pm 0.7$ & $3.3 \pm 0.4$ \\
\hline & $\mathrm{H}_{2} \mathrm{SO}_{4}$ & $80.5 \pm 0.5$ & $5.0 \pm 0.5$ & $1.2 \pm 0.8$ & $75.6 \pm 0.4$ & $75.4 \pm 0.5$ & $3.7 \pm 0.3$ \\
\hline \multirow{2}{*}{ SPL 2} & $\mathrm{HCl}$ & $92.2 \pm 0.8$ & $59.2 \pm 0.8$ & $50.2 \pm 0.8$ & $40.3 \pm 0.7$ & $15.5 \pm 0.5$ & $4.6 \pm 0.3$ \\
\hline & $\mathrm{H}_{2} \mathrm{SO}_{4}$ & $93.5 \pm 0.5$ & $45.7 \pm 0.3$ & $40.3 \pm 0.7$ & $42.5 \pm 0.5$ & $30.4 \pm 0.6$ & $4.5 \pm 0.3$ \\
\hline
\end{tabular}

Table 3: Morphometric indices of Lepidium sativum after seed treatment with SPL solutions of Pseudomonas sp. PS-17 strain

\begin{tabular}{|c|c|c|c|c|c|c|c|}
\hline \multirow[b]{2}{*}{ Dilution } & \multirow[b]{2}{*}{$\begin{array}{c}\text { Germi- } \\
\text { nation, \% }\end{array}$} & \multicolumn{2}{|c|}{4 days } & \multicolumn{2}{|c|}{9 days } & \multicolumn{2}{|c|}{16 days } \\
\hline & & $\begin{array}{c}\text { Shoot length, } \\
\mathrm{cm}\end{array}$ & $\begin{array}{l}\text { Root length, } \\
\mathrm{cm}\end{array}$ & $\begin{array}{c}\text { Shoot length, } \\
\mathrm{cm}\end{array}$ & $\begin{array}{l}\text { Root length, } \\
\mathrm{cm}\end{array}$ & $\begin{array}{c}\text { Shoot length, } \\
\mathrm{cm}\end{array}$ & $\begin{array}{l}\text { Root length, } \\
\mathrm{cm}\end{array}$ \\
\hline $\begin{array}{c}\text { Control } \\
\left(\mathrm{H}_{2} \mathrm{O}\right)\end{array}$ & 98 & $2.64 \pm 0.15$ & $4.31 \pm 0.14$ & $4.16 \pm 0.13$ & $7.72 \pm 0.16$ & $6.11 \pm 0.14$ & $9.10 \pm 0.14$ \\
\hline $1: 150$ & 98 & $2.78 \pm 0.13$ & $5.08 \pm 0.14$ & $4.18 \pm 0.15$ & $7.36 \pm 0.16$ & $6.13 \pm 0.18$ & $9.12 \pm 0.18$ \\
\hline $1: 100$ & 98 & $2.76 \pm 0.13$ & $5.06 \pm 0.13$ & $4.66 \pm 0.16$ & $7.38 \pm 0.18$ & $6.64 \pm 0.19$ & $9.55 \pm 0.18$ \\
\hline $1: 50$ & 98 & $2.79 \pm 0.14$ & $4.38 \pm 0.15$ & $5.02 \pm 0.18$ & $7.62 \pm 0.19$ & $6.12 \pm 0.18$ & $11.09 \pm 0.17$ \\
\hline $1: 25$ & 98 & $3.12 \pm 0.15$ & $3.84 \pm 0.13$ & $5.42 \pm 0.16$ & $6.84 \pm 0.17$ & $6.21 \pm 0.19$ & $10.08 \pm 0.17$ \\
\hline $1: 10$ & 97 & $2.94 \pm 0.15$ & $3.14 \pm 0.14$ & $5.46 \pm 0.18$ & $6.54 \pm 0.15$ & $6.31 \pm 0.17$ & $11.52 \pm 0.19$ \\
\hline $1: 5$ & 84 & $1.58 \pm 0.13$ & $0.86 \pm 0.11$ & $3.16 \pm 0.17$ & $2.78 \pm 0.18$ & $5.02 \pm 0.18$ & $5.31 \pm 0.18$ \\
\hline $1: 1$ & 76 & 0 & 0 & 0 & 0 & 0 & 0 \\
\hline
\end{tabular}




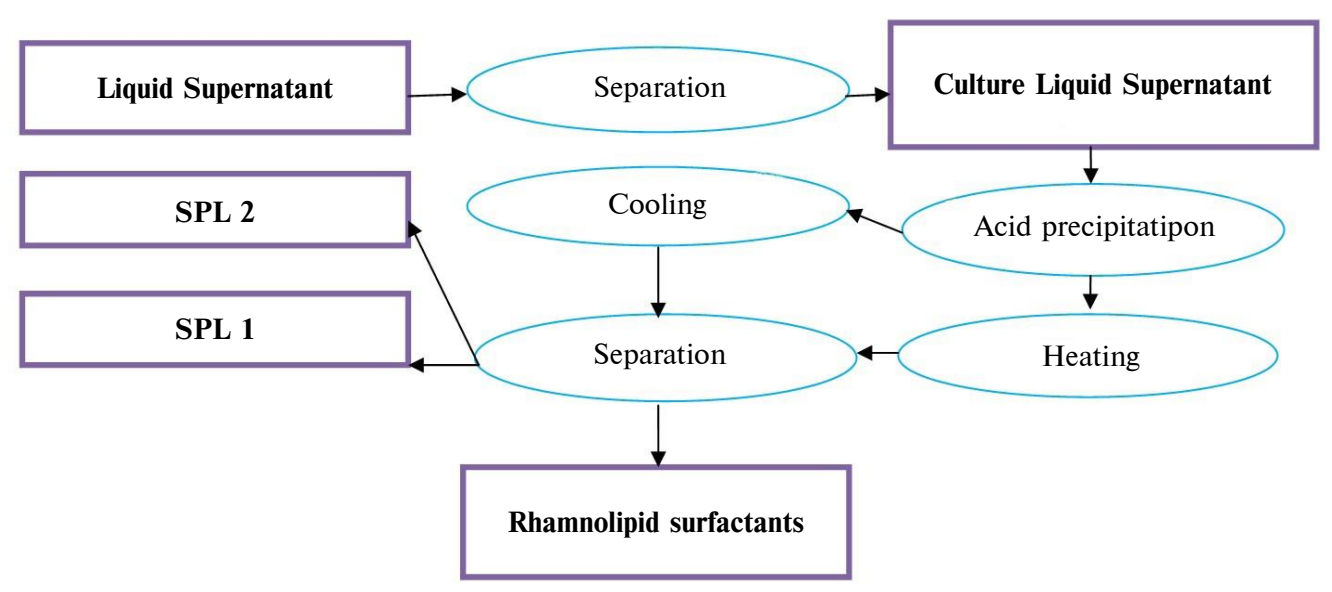

Figure: The scheme of Pseudomonas strains biosurfactants isolation

Thus, a new wasteless technology for Pseudomonas strains biosurfactants isolation has been elaborated (the Figure). The technology includes the solvent extraction stage.

The identified physico-chemical properties (emulsification, wetting, foaming) of the obtained products, as well as their low toxicity, are a real basis for their use in agricultural technologies (e.g. plant growth stimulation), the remediation of contaminated soils, in detergent compositions as it was shown in our previous works $[19,20]$.

\section{Discussion}

Rhamnolipids are effective surface-active products synthesized by the bacteria of the genus Pseudomonas. It is known, that the processes of biosurfactants isolation make up to $50-80 \%$ of the total cost of their production [2]. In addition, physico-chemical and biological properties of biosurfactants, which are necessary for the assessment of practical potential in specific industries, are still not sufficiently characterized.

Currently, solvents are often used for extraction and purification of biosurfactants, but they do not extract products completely, and also are toxic. The economic feasibility of rhamnolipids can be increased via obtaining their complexes: culture liquid supernatant, rhamnolipid biocomplex, etc. The maximum use of components of the postfermentative culture liquid can also be a rational method to the increase in production efficiency.

In this work, the methods of rhamnolipid surfactant isolation from the CLS of Pseudomonas strains using different acids and different temperature regimes were improved. The rational parameters for the deposition of biosurfactants of Pseudo- monas strains were developed. The advisability of surfactants isolation from the CLS of Pseudomonas sp. PS-17 and P. fluorescens 8573 by acid precipitation with obtaining of biosurfactant precipitate and supernatant was established. The optimum mode of acid precipitation of surfactants was determined - heating of the CLS to $100^{\circ} \mathrm{C}$ for $25 \mathrm{~min}$. As a result, the yield of the rhamnolipid surfactant concentrate was increased up to $20 \%$. Thus, the advantages of the developed method are the time saving, energy costs reduction due to the absence of the cooling stage of the acidified CLS as well as an increase in the yield of the product.

The physico-chemical properties of SPL (after the precipitation of biosurfactants from CLS of the Pseudomonas strains) for the evaluation of their practical potential were investigated. SPLs, obtained by acidification and followed cooling, are capable of emulsifying hydrophobic substances (various oils, fats, hydrocarbons).

The differences in emulsifying and foaming properties of SPL, obtained by various methods, are explained by a lower concentration of surfactants in SPL, obtained with heating, due to their more complete precipitation. Obviously, SPL obtained by this method are promising for composite detergents (with other surfactants), in cosmetics - for emulsifying oils and fats, etc. SPL obtained with cooling can also be used for the remediation of oilcontaminated soils (due to emulsifying properties). The wetting properties of SPL are important for the removal of oily stains, soot, and metallic dust from hydrophobic surfaces. Moisturizing properties of SPL also can be used in the pharmaceutical, cosmetic means. It is also shown that SPL (in dilutions of 1:10 and more) do not show a phytotoxic effect, but even stimulate the growth of watercress. 
Table 4: Comparative characteristics of biosurfactants of Pseudomonas strains with commercial preparations

\begin{tabular}{|l|c|c|c|c|c|}
\hline \multicolumn{1}{|c|}{$\begin{array}{c}\text { Product } \\
\text { characteristics }\end{array}$} & $\begin{array}{c}\text { Pseudomonas } \\
\text { biosurfactants }\end{array}$ & $\begin{array}{c}\text { Sodium } \\
\text { dodecyl-sulphate }\end{array}$ & Triton X-100 & $\begin{array}{c}\text { AGAE } \\
\text { Technologies }\end{array}$ & $\begin{array}{c}\text { Urumqi Unite } \\
\text { Biotechnology }\end{array}$ \\
\hline $\begin{array}{l}\text { Critical micelle } \\
\text { concentration, g/ }\end{array}$ & $0.05-0.14$ & 0.26 & 0.65 & $0.02-0.15$ & $0.05-0.10$ \\
\hline $\begin{array}{l}\text { Interfacial tension } \\
\text { (water-kerosene), } \\
\text { mN/m }\end{array}$ & $0.009-0.2$ & 0.1 & 0.4 & 0.08 & 0.09 \\
\hline Foaming capacity & 7 & 8 & 6 & 9 & 6 \\
\hline Price, USD/kg & $70-180$ & 90 & 70 & 320 & $400-1600$ \\
\hline
\end{tabular}

SPLs can be a promising agent for crop production, a basis for detergents (with other surfactants), as components of anticorrosive compositions, etc. [21, 22].

Thus, a new wasteless technology for Pseudomonas strains biosurfactants isolation has been proposed. This technology has economic and environmental advantages.

Thanks to the strategic planning technique used to identify strengths, weaknesses, opportunities, and threats related to the obtained biosurfactant products (SWOT-analysis) [23] it has been shown that their advantages over synthetic ones are high efficiency, heat resistance, non-toxicity, biocompatibility and biodegradability (Table 4). Renewable raw materials including production waste can be used for the biosynthesis. It is shown that their predicted cost is $70-180 \mathrm{USD} / \mathrm{kg}$ depending on the concentration, whereas for commercial biosurfactant (Urumqi Unite Bio-Technology, AGAE Technologies) - 320-1600 USD/kg [24]. Thus, the unique physicochemical and biological properties of the obtained substances, their low toxicity, and the mild effect on the cells of microorganisms and plants are a powerful argument for their use as environmentally safe products in modern industrial and agricultural technologies. So, thanks to polyfunctional properties and environmental safety, the obtained surfactants of Pseudomonas strains will be competitive in the modern market as independent products and components of complex products for modern industrial and agricultural technologies.

\section{Conclusions}

The rational technology for Pseudomonas strains biosurfactants isolation has been proposed. It was shown that an effective way to isolate biosurfactants Pseudomonas sp. PS-17 and P. fluorescens 8573 is acidic precipitation from CLS with heating. As a result, the yield of the biosurfactant concentrate is increased by $20 \%$, and the duration of the process is reduced.

The physic-chemical properties of SPL after isolating the rhamnolipid concentrate from the culture liquid supernatant were studied. SPLs have been shown to be effective oil emulsifiers, foaming and wetting agents for various surfaces.

It was found that SPL (at 1:10 dilutions) do not show phytotoxic effects and stimulate the growth of watercress.

SPL as a cheap effective product can be used in environmentally friendly technologies: for agriculture, remediation of contaminated soils, detergents, etc.

\section{References}

[1] Mir Sh, Jamal P, Alama MdZ, Mir AB, Ansari AH. Microbial surface tensio-active compounds: production and industrial application perspectives. Int J Biotechnol Bioeng. 2017;3(8):273-92.

[2] Chong H, Li Q. Microbial production of rhamnolipids: opportunities, challenges and strategies. Microb Cell Fact. 2017;16:13. DOI: $10.1186 / \mathrm{s} 12934-017-0753-2$.

[3] Lotfabad T, Ebadipour N, RoostaAzad R. Evaluation of a recycling bioreactor for biosurfactant production by Pseudomonas aeruginosa MR01 using soybean oil waste. J Chem Technol Biotechnol. 2016;91(5):1368-77. DOI: 10.1002/jctb.4733

[4] Gudiña E, Rodrigues A, de Freitas V, Azevedo Z, Teixeira J, Rodrigues L. Valorization of agro-industrial wastes towards the production of rhamnolipids. Biores Technol. 2016;212:144-50. DOI: 10.1016/j.biortech.2016.04.027 
[5] Li Q. Rhamnolipid synthesis and production with diverse resources. Front Chem Sci Eng. 2017;11(1):27-36. DOI: $10.1007 / \mathrm{s} 11705-016-1607-\mathrm{x}$

[6] Yerokhin V, Pokynbroda T, Karpenko O, Novikov V. Study of the growth and synthesis of the target product by the strain Pseudomonas species PS-17 - producent of extracellular biosurfactants. Visnyk Natsionalnoho Universytetu Lvivska Politekhnika. 2006;553:124-7.

[7] Pokynbroda T, Karpenko O. Synthesis of biosurfactants by Pseudomonas strains on biodiesel production waste. Proceedings of Internet Conference Biotechnology: Experience, Traditions and Innovations; 2016 December. p. 155-60. Available from: http://old.nuft.edu.ua/page/51adaed39c2a2/files/\%D0\%A2\%D0\%B5\%D0\%B7\%D0\%B8.pdf

[8] Kaskatepe B, Yildiz S, Gumustas M, Ozkan S. Biosurfactant production by Pseudomonas aeruginosa in kefir and fish meal. Braz J Microbiol. 2015;46(3):855-9. DOI: 10.1590/S1517-838246320140727

[9] Henkel M, Schmidberger A, Vogelbacher M, Kühnert C, Beuker J, Bernard T, et al. Kinetic modeling of rhamnolipid production by Pseudomonas aeruginosa PAO1 including cell density-dependent regulation. Appl Microbiol Biotechnol. 2014;98(16):7013-25. DOI: 10.1007/s00253-014-5750-3

[10] Karpenko OV, Pokynbroda TYa, Makitra RG. Optimal methods for the isolation of biogenic surface-active rhamnolipids. Zhurnal Obschej Khimii. 2009;79(12):2011-4.

[11] Beuker J, Steier A, Wittgens A, Rosenau F, Henkel M, Hausmann R. Integrated foam fractionation for heterologous rhamnolipid production with recombinant Pseudomonas putida in a bioreactor. Amb Express. 2016;6:11. DOI: $10.1186 / \mathrm{s} 13568-016-0183-2$

[12] Scott M, Jones M. The biodegradation of surfactants in the environment. Biochim Biophys Acta. 2000;1508(1-2):235-51. DOI: $10.1016 / \mathrm{S} 0304-4157(00) 00013-7$

[13] Mixich J, Rothert R, Wullbrandt D. Process for the quantitative purification of glycolipids. United States patent 5656747A. 1997.

[14] Kłosowska-Chomiczewska IE, Mędrzycka K, Hallmann E, Karpenko E, Pokynbroda T, Macierzanka A, et al. Rhamnolipid CMC prediction. J Colloid Interface Sci. 2017;488:10-9. DOI: 10.1016/j.jcis.2016.10.055

[15] Guerra-Santos L, Kappeli O, Fiechter A. Pseudomonas aeruginosa biosurfactant production in continuous culture with glucose as carbon source. Appl. Environ Microbiol. 1984;48(2):301-5.

[16] Kuksis A. Chromatography of lipids in biomedical research and clinical diagnosis. 1st ed. Amsterdam: Elsevier; 1987.459 p.

[17] Seeds of agricultural plants. Methods for seed testing. Kyiv: Derzhspozhivstandart Ukrayini; 2003. 148 p. DSTU 4138-2002.

[18] Fire safety. General purpose frothers for extinguishing fires. General technical requirements and test methods. Kyiv: Derzhspozhivstandart Ukrayini; 2016. 32 p. DSTU 3789:2015.

[19] Karpenko O, Banya A, Baranov V, Novikov V, Kołwzan B. Influence of biopreparations on phytoremediation of petroleumcontaminated soil. Pol J Environ Stud. 2015;24(5):2009-15. DOI: 10.15244/pjoes/42672

[20] Karpenko E, Voloshynets V, Karpenko I, Pokynbroda T, Semenyuk I, Midyana H. Colloidal Characteristics of water systems of rhamnolipid biocomplex of strain Pseudomonas sp. PS-17 with Tween-80 and their prospects for biotechnology. Innov Biosyst Bioeng. 2018;2(1):57-63. DOI: 10.20535/ibb.2018.2.1.127258

[21] Karpenko O, Pokynbroda T, Lubenets V, Martynyuk N, Zin I. Biosynthesis of surfactants by the microorganisms of the genera Pseudomonas in soybean oil and the study of their properties. Visnyk Natsionalnoho Universytetu Lvivska Politekhnika. 2017;868:222-9.

[22] Shulga O, Joegel J, Karpenko O, Prystai M, Vildanova R. Surface-active complexes of the strain Pseudomonas aeruginosa JRV-1. Visnyk Natsionalnoho Universytetu Lvivska Politekhnika. 2017;868:179-86.

[23] SWOT Analysis - Discover New Opportunities, Manage and Eliminate Threats [Internet]. Mindtools.com. 2019 [cited 2018 Feb 24]. Available from: https://www.mindtools.com/pages/article/newTMC_05.htm

[24] Global Biological Surfactant Market 2018 Growth By Players:- Evonik, Agae Technologies, Biotensidon, Ecover, Jeneil Biotech, Logos Technologies - Industry News Today [Internet]. Industry News Today. 2019 [cited 2019 Feb 26]. Available from: http://industrynewstoday.com/7119/global-biological-surfactant-market-2018-growth-by-players-evonik-agae-technologiesbiotensidon-ecover-jeneil-biotech-logos-technologies/

Т.Я. Покиньброда, І.В. Карпенко, Г.Г. Мідяна, О.Я. Карпенко

\section{ВИДІЛЕННЯ СУРФАКТАНТІВ БАКТЕРІЙ PSEUDOMONAS I ДОСЛІДЖЕННЯ ЇХ ВЛАСТИВОСТЕЙ}

Проблематика. Важливою проблемою виробництва біосурфактантів $є$ оптимізація біосинтезу, проте найбільші труднощі існуючих технологій - відсутність ефективних методів їх виділення для отримання нових економічно вигідних продуктів.

Мета. Розробка раціональної технології виділення біосурфактантів штамів Pseudomonas sp. PS-17 і P. fluorescens 8573 . Bивчення впливу різних кислот і температурних умов на ефективність виділення сурфактантів штамів Pseudomonas і дослідження властивостей отриманих продуктів. Визначення потенційних напрямів використання одержаного продукту - надосадової рідини, отриманої після осадження біокомплексів. 
Методика реалізації. Рамноліпідний біокомплекс осаджували із супернатанту культуральної рідини підкисленням розчинами кислот $\left(\mathrm{HCl}, \mathrm{H}_{2} \mathrm{SO}_{4}, \mathrm{H}_{3} \mathrm{PO}_{4}, \mathrm{HNO}_{3}, \mathrm{CH}_{3} \mathrm{COOH}\right)$, витримували при $100^{\circ} \mathrm{C} 25$ хв або охолоджували, центрифугували, надосадову рідину декантували. Поверхневий натяг біогенних поверхнево-активних речовин визначали методом дю Нуї з платиновим кільцем. Індекс емульгування біосурфактантів визначали щодо вазелінової та соняшникової олій. Ліпіди виділяли з надосадової рідини екстракцією етилацетатом з ізопропанолом, склад визначали за допомогою тонкошарової хроматографії. Вплив на рослини оцінювали за морфометричними показниками після передпосівної обробки насіння.

Результати. Розроблено раціональну технологію виділення поверхнево-активних речовин штамів Pseudomonas sp. PS-17 і $P$. fluorescens 8573. Показано, що найбільш прийнятним методом виділення рамноліпідних біосурфактантів $€$ їх кислотне осадження із супернатанту культуральної рідини з нагріванням. У результаті вихід продукту збільшився на $20 \%$, а тривалість процесу скоротилася. Вивчено фізико-хімічні властивості надосадової рідини після виділення біокомплексів. Показано, що вона $\epsilon$ ефективним емульгатором, піноутворювачем і змочувальним агентом для різних поверхонь. Надосадова рідина в розведенні 1:10 не проявляє фітотоксичного ефекту й стимулює ріст крес-салату.

Висновки. Запропоновано нову безвідходну технологію виділення біосурфактантів штамів роду Pseudomonas, яка передбачає виключення стадії екстракції розчинниками, у результаті підвищується вихід цільових продуктів. Показано, що надосадова рідина як дешевий продукт може використовуватися в екологічно чистих технологіях: для сільського господарства (стимулювання росту рослин), рекультивації забруднених ґрунтів, у складі мийних композицій.

Ключові слова: рамноліпідні сурфактанти; фізико-хімічні властивості; кислотне осадження; стимулятори росту рослин.

Т.Я. Покиньброда, И.В. Карпенко, Г.Г. Мидяна, А.Я. Карпенко

\section{ВЫДЕЛЕНИЕ БИОСУРФАКТАНТОВ БАКТЕРИЙ РSЕUDOMONAS И ИЗУЧЕНИЕ ИХ СВОЙСТВ}

Проблематика. Важной проблемой производства биосурфактантов является оптимизация биосинтеза, но наибольшие трудности существующих технологий - отсутствие эффективных методов их выделения для получения новых экономически выгодных продуктов.

Цель. Разработка рациональной технологии выделения биосурфактантов штаммов Pseudomonas sp. PS-17 и P. fluorescens 8573. Изучение влияния различных кислот и температурных условий на эффективность выделения сурфактантов штаммов Pseudomonas и исследование свойств полученных продуктов. Определение потенциальных направлений использования полученного продукта - надосадочной жидкости, полученной после осаждения биокомплексов.

Методика реализации. Рамнолипидный биокомплекс осаждали из супернатанта культуральной жидкости подкислением растворами кислот ( $\left.\mathrm{HCl}, \mathrm{H}_{2} \mathrm{SO}_{4}, \mathrm{H}_{3} \mathrm{PO}_{4}, \mathrm{HNO}_{3}, \mathrm{CH}_{3} \mathrm{COOH}\right)$, выдерживали при $100^{\circ} \mathrm{C} 25$ мин или охлаждали, центрифугировали, надосадочную жидкость декантировали. Поверхностное натяжение биогенных поверхностно-активных веществ определяли методом дю Нуи с платиновым кольцом. Индекс эмульгирования биосурфактантов определяли относительно вазелинового и подсолнечного масел. Липиды выделяли из надосадочной жидкости экстракцией этилацетатом с изопропанолом, состав определяли тонкослойной хроматографией. Влияние на растения оценивали по морфометрическим параметрам после предпосевной обработки семян.

Результаты. Разработана рациональная технология выделения поверхностно-активных веществ штаммов Pseudomonas sp. PS-17 и $P$. fluorescens 8573. Показано, что наиболее приемлемым методом выделения рамнолипидных биосурфактантов является их кислотное осаждение из супернатанта культуральной жидкости с нагреванием. В результате выход продукта был увеличен на $20 \%$, а продолжительность процесса уменьшилась. Изучены физико-химические свойства надосадочной жидкости после выделения биокомплексов. Показано, что надосадочная жидкость является эффективным эмульгатором, пенообразователем и смачивающим агентом различных поверхностей. Надосадочная жидкость в разведениях 1:10 не проявляет фритотоксического эффректа и стимулирует рост кресс-салата.

Выводы. Предложена новая безотходная технология выделения биосурфактантов штаммов рода Pseudomonas, которая предусматривает исключение стадии экстракции растворителями, в результате повышается выход целевых продуктов. Таким образом, эта технология имеет экономические и экологические преимущества. Было показано, что надосадочные жидкости как дешевый продукт могут использоваться в экологически чистых технологиях: для сельского хозяйства (стимулирование роста растений), рекультивации загрязненных почв, в составе моющих композиций.

Ключевые слова: рамнолипидные сурфактанты; физико-химические свойства; кислотное осаждение; стимуляторы роста растений. 